\title{
Sea-blue histiocytes and Gaucher cells in bone marrow of patients with chronic myeloid leukaemia
}

\author{
P R KELSEY, C G GEARY \\ From the Department of Haematology, Royal Infirmary, Manchester
}

SUMMARY A retrospective study of 211 bone marrow aspirates from patients with chronic myeloid leukaemia (CML) was undertaken to assess the incidence of Gaucher cells and sea-blue histiocytes. A significant correlation between the presence of these cells and prolonged survival was seen. Such storage histiocytes occurred most often during periods of relapsed chronic phase. This study shows that Gaucher cells and sea blue histiocytes are a common feature of CML and that their accumulation seems to be associated with a prolonged increase in leucocyte turnover.

The presence of Gaucher-like cells in the bone marrow of some patients with chronic myeloid leukaemia (CML) was first described over 20 years ago,' and several further reports followed over the next few years. $^{2-4}$ These cells were subsequently shown to be histochemically and ultrastructurally identical with those seen in the inherited form of Gaucher's disease. ${ }^{5}$ The presence of sea-blue histiocytes, similar to those seen in the syndrome of sea-blue histiocytosis, was reported in the same year. ${ }^{6}$

We recently observed large numbers of Gaucher cells in the bone marrow of a patient with CML whose survival was unusually prolonged. We set out to discover both the incidence of these cells in this disease, and whether there was an association between their presence and various other disease variables, including survival.

\section{Material and methods}

We reviewed all available archive material from patients with CML seen in this department between 1975 and 1986. Bone marrow smears stained with Romanovsky stain were examined by low power microscopy and a semiquantitative assessment of the number of Gaucher cells or sea-blue histiocytes, or both, was made in terms of their number in each low field. By arbitrarily dividing the cases we produced three groups: (i) those showing "many" Gaucher cells (> 3 per 10 low power fields); (ii) those showing "few" ( $<3$ per 10 power fields); (iii) those showing "none" ( $<2$ identifiable cells). The clinical records for all patients were reviewed and the stage of disease corresponding to each marrow sample classified as follows: (i) presentation; (ii) stable chronic phase

Accepted for publication 17 March 1988 (white cell count of $<15 \times 10^{9} / 1$ ); (iii) relapsed chronic phase (white cell count of $>15 \times 10^{9} / 1$ ); (iv) hypoplasia/aplasia (white cell count of $<3 \times 10^{9} / 1$, platelets of $<100 \times 10^{9} / 1$ with hypocellular marrow); (v) blast transformation.

\section{Results}

Two hundred and eleven marrow aspirates from 69 patients were examined and Gaucher cells or sea-blue histiocytes were found in 30 patients at some time during the course of their disease. Only eight patients $(12 \%)$ ever showed "many" cells, and in only two cases were the cells numerous.

Three types of abnormal storage cells have been described in CML marrows:

1 "Typical" Gaucher cells-these are large, round, or oval cells, some $30-60 \mu \mathrm{m}$ in diameter, usually oval and with a single nucleus, fine granularity of the cytoplasm and characteristic fibrillary or onion skin appearance (fig 1).

2 Blue cells similar to those seen in the syndrome of sea-blue histiocytosis. These lack the fibrillary cytoplasmic pattern and contain numerous deep blue granules (fig 2).

3 Intermediate cells exhibiting features of both Gaucher cells and sea-blue histiocytes. These cells generally show morphological resemblance to Gaucher cells (fig 3).

Of our 30 positive cases, 11 showed only Gaucher cells and five showed only sea-blue histiocytes; the remainder showed a mixture of the three morphological types of histiocyte.

SUR VIVAL

When patients were split into three groups, based on the presence of these cells at some time during their 

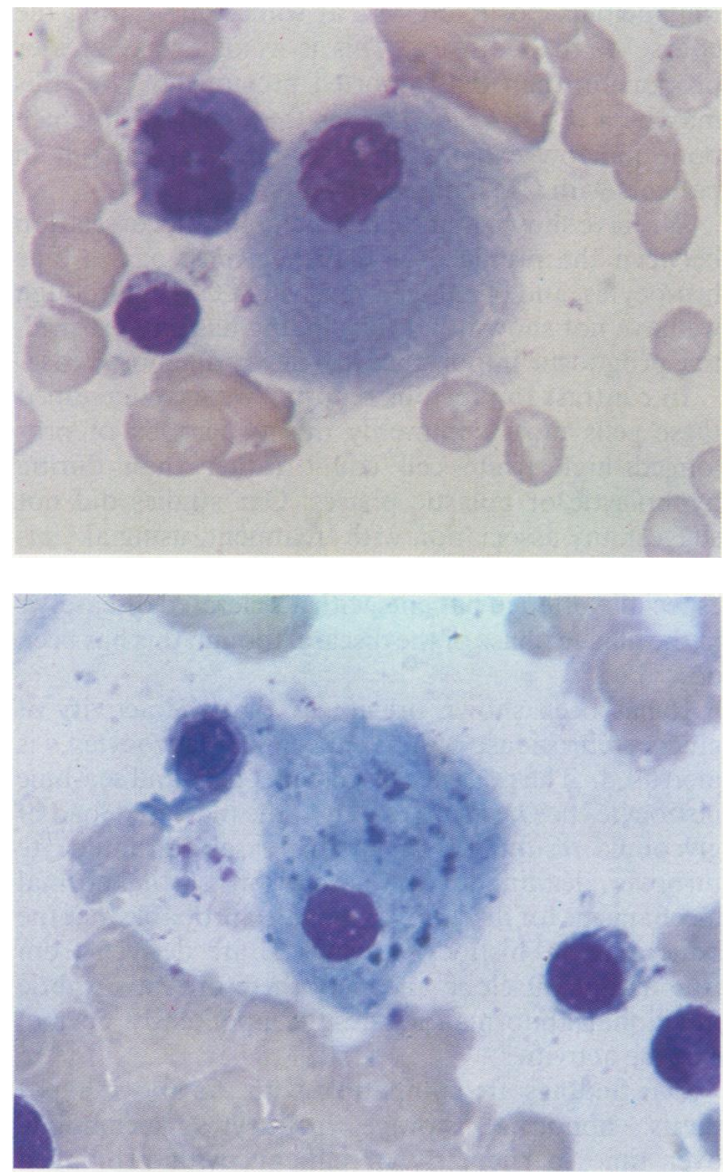

disease, a highly significant correlation was found between the finding of "many" abnormal histiocytes and prolonged survival. Those patients with "none" survived a mean of 39.7 months from diagnosis of CML, those with "few", 50.1 months, and those with "many" 124.9 months $(p=0.0008)$. A less significant correlation was found between the presence of "few" such cells and survival.

We found no significant correlation between the presence of these cells at diagnosis and the duration of survival, although only one patient fell into the "many" group and her follow up to date is short. Using covariant analysis we examined the possibility that the appearance of blue cells during the course of the disease was associated with an improved expectation of survival from that time. We found that this was a variable of moderate independent significance $(p=$ 0.03 ). In the same analysis we found that age

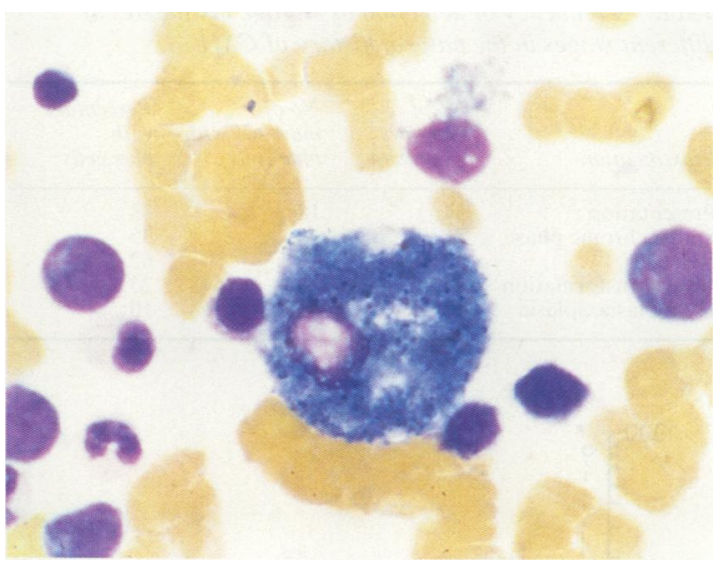

Fig 1 Typical "Gaucher" cell from a CML marrow.

Fig 2 Sea-blue histiocyte from a CML marrow.

Fig 3 Intermediate blue histiocyte from a CML marrow.

correlated strongly with length of survival, but gender did not.

We next examined various disease variables to define their association with the presence of "blue cells". There was no correlation between the presence of such cells and age, sex, white cell count at presentation, platelet count, haemoglobin concentration or size of spleen. It became apparent, however, that these cells occurred most often in those cases where the white cell count remained high for prolonged periods. When we analysed the number of marrows examined in the various stages of the disease it became apparent that the highest incidence of positive marrows was seen during periods of relapsed chronic phase (table). When an individual case is analysed over several years this association between the white cell count and the presence of storage histiocytes is clearly demonstrable (fig 4). 
Table Frequency of detection of storage histiocytes at different stages in the natural history of CML.

\begin{tabular}{llll}
\hline & $\begin{array}{l}\text { No of } \\
\text { marrous } \\
\text { examined }\end{array}$ & $\begin{array}{l}\text { No of } \\
\text { marrows with } \\
\text { hlue cells }\end{array}$ & $\begin{array}{l}\text { Percentage } \\
\text { with } \\
\text { blue cells }\end{array}$ \\
\hline Presentation & 54 & 18 & 33 \\
Stable chronic phase & 75 & 26 & 35 \\
Relapse & 37 & 23 & 62 \\
Blast transformation & 35 & 8 & 23 \\
Hypoplasia aplasia & 10 & 1 & 10 \\
\hline
\end{tabular}

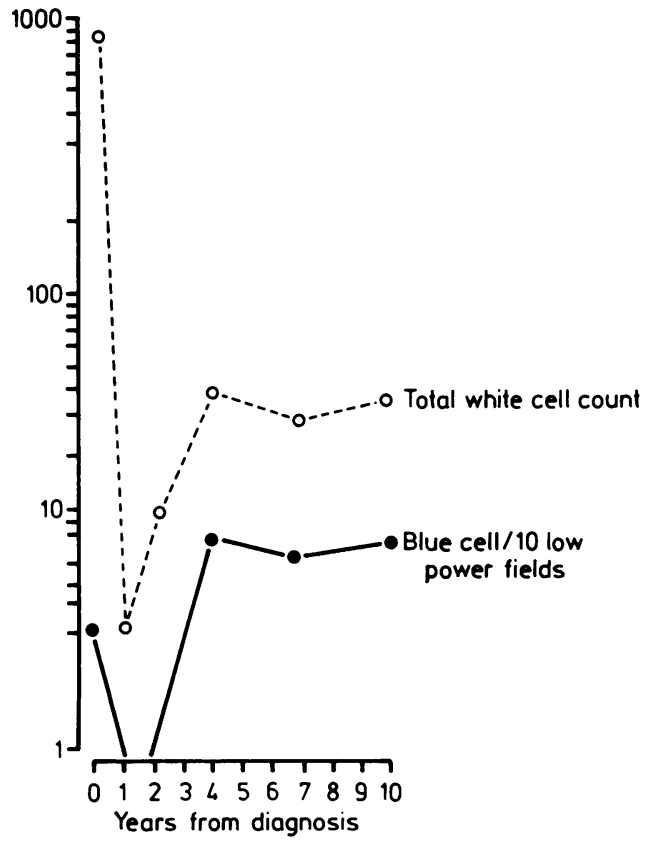

Fig 4 Relation between peripheral blood white cell count and presence of bone marrow storage histiocytes in an individual patient with $C M L$.

\section{Discussion}

Gaucher's disease is an inherited disorder of sphingolipid metabolism caused by a deficiency of glucocerebrosidase. The presence of Gaucher cells was considered to be pathognomonic of the disease until 1966 when Albrecht described them in a case of CML, and they have subsequently been noted, although rarely, in other disorders. There have been few systematic studies of the importance of Gaucher cells in the evolution of CML, though Dosik et al found that they were occasionally seen in patients accidentally made hypoplastic after chemotherapy. ${ }^{4}$

We have found that abnormal histiocytes occur in the bone marrow of up to $40 \%$ of patients with
Philadelphia positive CML at some time during the course of their disease. This is a somewhat greater proportion than that reported previously, ${ }^{14}$ but this may be a result of the greater frequency with which bone marrow examination has been carried out in patients with CML in recent years.

We have shown that there is a significant correlation between the presence of Gaucher cells, or sea-blue histiocytes, and prolonged survival in CML, although we have not shown that this finding has any prospective prognostic importance in a newly diagnosed case.

In contrast to previous reports, ${ }^{4}$ we have identified these cells most commonly during periods of prolonged high white cell count rather than during hypoplastic or aplastic phases. Our studies did not suggest any association with treatment, using akylating agents, or thioguanine, nor did these cells occur especially often in patients with accelerated disease, or in the blastic phase of the disease, though this has been described. ${ }^{5}$

It has been shown previously that the activity of glucocerebrosidase in leukaemic leucocytes is increased. ${ }^{7}$ The presence of Gaucher cells and sea-blue histiocytes has been attributed to the increased load of glycolipid resulting from the increase in granulocyte turnover, leading to the saturation of the normal mechanisms for its removal. It is also probable that the bone marrow histiocytes in CML are derived from the malignant clone and may therefore have subtle functional abnormalities despite apparently normal enzyme activities.

Our findings are compatible with the above hypothesis: abnormal storage histiocytes accumulate over time, particularly in patients with prolonged high white cell counts. The association with survival presumably reflects this time-dependent accumulation.

\section{References}

1 Albrecht M. "Gaucher-Zellen" bei chronisch myeloischer leukamie. Blut 1966:13:169-79.

2 Smith WC. Kaneshiro MM. Goldstein BD. Parker JW. Lukes FJ. Gaucher cells in chronic granulocytic leukaemia. Lancet 1968;ii:780-1.

3 Rosner F. Dosik H, Kaiser SS, Lee SL, Morrison AN. Gaucher cells in leukaemia. JAMA 1969:88:194-8.

4 Dosik H, Rosner F, Sawitsky A. Acquired lipidosis: Gaucher-like cells and "blue-cells" in chronic granulocytic leukaemia. Semin Haematol 1972;9:309-16.

5 Gerdes J. Marathe RL. Bloodworth JMB. MacKinney AA. Gaucher cells in chronic granulocytic leukaemia. Archives of Pathology 1969:88:194-8.

6 Kattlove HE, Williams JC. Gaynor E, Spivack M, Bradley RM, Brady RO. Gaucher cells in chronic myelocytic leukaemia: an acquired abnormality. Blood 1969;33:379-90.

7 Kampine JP, Brady RO, Yarkee RA, Kaufer JN, Shapiro D. Gal AE. Shingolipid metabolism in leukaemic leukocytes. Cancer Res 1967;27:1312-5. 